\title{
Development of Corporate Social Initiative (CSI) Model for Micro, Small and Medium Enterprises in Indonesia
}

\author{
Ghia Subagja*, Mediya Destalia, Damayanti \\ Jurusan Administrasi Bisnis \\ Universitas Lampung \\ Bandar Lampung, Indonesia \\ *ghia.subagja@fisip.unila.ac.id, mediya.destalia@fisip.unila.ac.id, Damayanti.1981@fisip.unila.ac.id
}

\begin{abstract}
This study aims to explore the social involvement impact of Micro, Small dan Medium Enterprises (MSMEs), consumers and a social community through the Corporate Social Initiative (CSI) program carried out by involving the social behaviour of consumers and community for their business sustainability in the future. This research uses a case study method with a qualitative approach, so the data collection technique is carried out by deep interviews and observations to MSME actors who implement CSI program indirectly. These informants consist of one owner, four managers, four employees and five consumers from one of the MSMEs engaged in the coffee industry. The results of this study show the important of CSI, which is a model and a solution for creating good relationships between MSMEs, consumers and social communities, it has a positive impact on the MSMEs image. The CSI program which done by MSMEs is inviting consumers to be actively involved in every social activity organized by MSMEs which collaborate with a social community. It has an impact on consumers who feel they are part of the MSMEs. MSMEs will have a very good competitive advantage for sustainability of their business.
\end{abstract}

Keywords-corporate social intiative, society, social bahavior, competitive advantage

\section{INTRODUCTION}

Dynamic social life brings change impact for every individual and multicultural group in Indonesia. Certainly, it also affects the role of the MSME business sector as a support for the national economy in recent years. The growth of MSMEs by $10 \%$ in the $2018-2019$ period [1] shows that this percentage increase has an impact on the competition of several MSMEs which have similar business lines to continue surviving and being sustainable in fulfill customer demand which increase every year. One of the growing business sectors is MSME players engaged in the coffee sector, especially coffee shops. This trend appears as a symbol of lifestyle changes which happen in society, especially the youths who tend to spend part of their activities in coffee shops, this change has begun to be addressed by some businessmen as a potential segment which is able to become a strength for having closer relationship between MSME players, in this case, the brands with consumers through various development programs. The majority of studies exploring the sustainability behaviour of SMEs have discussed their social and environmental practices as a topic called "corporate social responsibility" (CSR) [2] as in practice in large companies.

Several studies reveal the differences in corporate motivation are based on two different concerns. MSME actors are faced with a development strategy or responsibility for the environment in it as a form of entity to customers.

Diskusi Kopi is one of the MSME players which run the coffee shop business industry that develops the CSI model through the sharing movement with the tagline Thanks god its Friday (Figure 1). The purpose of this program is to gather business actors and customers participating voluntarily to donate products in the form of food every Friday and every costumer who comes can try a variety of food menus for free then share with cross-communities to enjoy the moment at the discussion spot and corner.

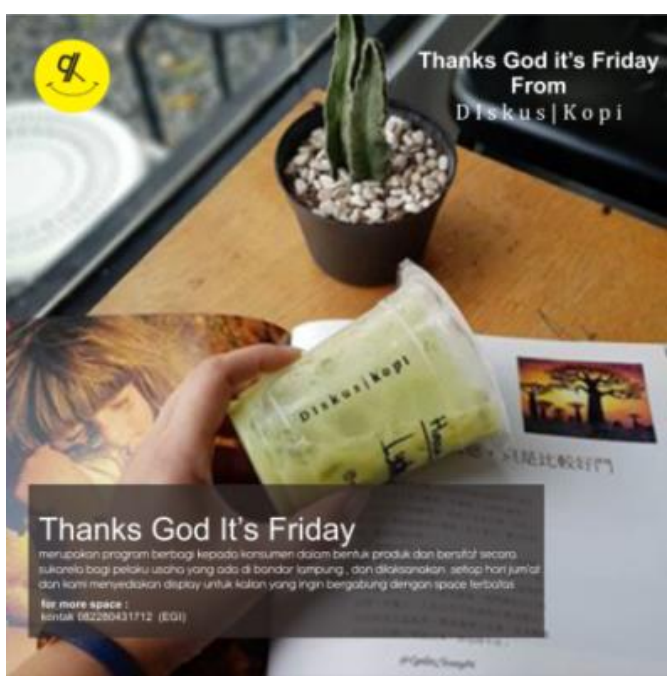

Source: Instagram of Diskusi Kopi 2020

Fig. 1. CSI community based social movement 
CSI is a new phenomenon in terms of implementations of the company to the community, one of them by using Cause Promotion or Social Campaign method as a company strategy to build public awareness and concern for a social movement, encourage community participation for fundraising, or recruit volunteers for the movement. Included in this type are initiatives to persuade people to become involved, donating time, money or non-monetary resources for a movement [3].

CSI is the manifestation of the humanistic marketing concept. Humanistic marketing began to develop from 2011. It was marked by the emergence of opinions from several experts, including Porter and Kramer [4] which stated that the perspective of "what is good for business is good for society" is an ancient perspective and needs to be replaced with a "what is" perspective, "what is good for society is good for business" [5]. From this change in perspective, the concept of humanistic marketing emerged, covering 3 aspects, namely visions, business goals and processes, and social impacts.

The development of this model exist from the attention of social behaviour in society which shifts to the context of collaboration as emerging trends and as an existence for consumer identity which is built in the brand community. The new consumer market in this study is formed to generate buying decisions which are influenced by corporate social responsibility (CSR) issues [6].

Consumers will push organizations to think consciously about their responsibilities to consumers as main stakeholders and place consumers on a common movement and program $[7,8]$.

The development of the CSI model is interesting to be investigated because it involves emotional representation between brands and individuals, as an action which reflects the change in consumer behaviour on brands which represent them, also it represents the existence of social life and as a new knowledge for MSME actors in running their business. This study aims to examine the relationship between the CSI-based MSME development model with consumer behaviour also the social impacts on business sustainability.

\section{RESEARCH METHODS}

This research is a qualitative descriptive study involving SMEs and consumers as well as communities who actively participate in movements and campaigns. Moleong [9] stated that qualitative research is a method for understanding individuals which is done integratively and comprehensively in order to obtain an in-depth understanding of the individual and the problems with the aim that the problem can be resolved and obtain good self-development. The approach used in this research is a case study approach, it aims to make it easier to collect information for understanding a problem from a study by the methods of an investigation, so the solutions for solving problems are obtained after the information is processed. To obtain data or information, researchers use interview techniques, observation and study documentation sourced from several parties; one business owner, three managers, two baristas, two consumers.

\section{RESULTS}

Diskusikopi is a coffee shop that was established in Bandar Lampung in June 2019, located at Jalan Teuku Umar No.99, Kedaton, Kec. Kedaton, Bandar Lampung City (right next to the PTPN VII office). Initially, Diskusikopi was founded by three owners, namely Pras, Egi and Aldi where the capital was a joint venture of the three people. The idea of establishing Diskusikopi was due to the large potential of robusta coffee suppliers in the Lampung area. Lampung is the robusta coffee largest producer in Indonesia. But on the other hand, the suppliers have not thought about making coffee ready to drink, like the packaging, which it can reach more consumers. This business activity is still being done by migrants from outside Lampung such as El's Coffee and Starbucks. Until then, there were not many local coffee brands which have middle class segmentation, thus when they saw an opportunity to establish a coffee shop which have a middle class segmentation, they named "Diskusikopi". Diskusi Kopi has several programs related to Corporate Social Initative (CSI). CSI, which is carried out by Diskusikopi UMKM business actors through the thanks god its Friday (TGIF) program, involves all elements between the community and business actors to be actively involved in providing voluntary donations. Several business actors and social communities contributed to the Thanks God It's Friday Program. Some of them are Potato Donuts R and Y, Martabak Oishi, Nasi Kemakmuran, Folding Hats, BMX Bike Community, Lampung CSR_Bike Community as shown in Figure 2.

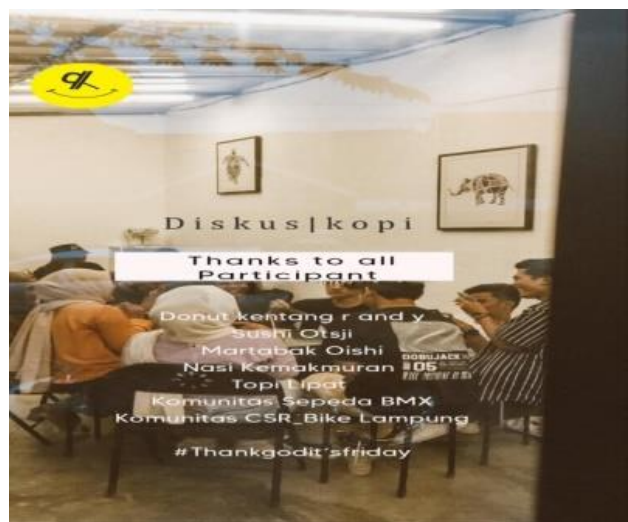

Source: Instagram account of Diskusi Kopi

Fig. 2. Acknowledgments for coffee discussions to business actors who have contributed to the Thanks God It's Friday Program.

At the very first time, this program was from some people who sent direct messages or DM message to Diskusi Kopi Instagram, who offered to sell their snacks at the shop. And some of snacks which was not sold or it remained little, those would be shared to others. From those, they were inspired to provide additional free snacks, usually in the kind of pudding, chocolate cake and others, and it was done every Friday and 
has been running since 2 months when Diskusi Kopi 2.0 shop opened. And when they were asked about the selection of Friday's special day, they said "Friday is a good day", and according to the barista there has been an increase in the number of cups sold on that day.

The TGIF program has had an impact offline through the high interest of potential consumers to visit and buy products in the program. Therefore, with the high interest of visitors, it can increase overall sales in each ongoing program.

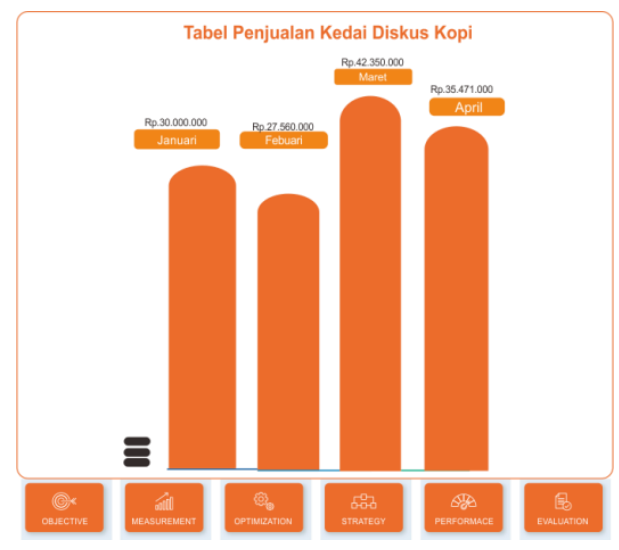

Source : Diskus Kopi 2020

Fig. 3. Graph of discus coffee sales for the Jan - April 2020 Period.

Based on Figure 3, it can be seen that there was an increase in income during the time span when the TGIF program was implemented between the February - March period. In addition, an increase also occurred in community behavioral activities to interact through social media, especially Instagram.

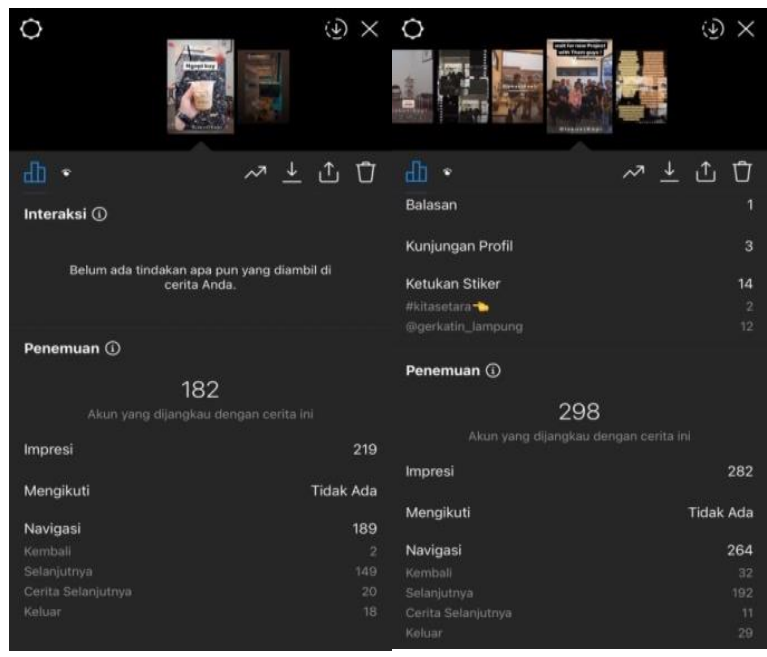

Source : Instagram of Diskus Kopi 2020

Fig. 4. Increased user interaction on instagram.

Based on figure 4, it shows the high enthusiasm of Instagram users, who are dominated by the youths, in the TGIF program has an impact on the social community to interact and also it becomes a flow of information for the youths, so they can involve theirselves in the program. The development of CSI is not only a model in the company's business strategy but can also be applied to business actors or MSME players, so they can contribute and be socially responsible based on the needs of consumers or communities. The impact from this study is the creation of a social community identity which represents a brand existing in a community voluntarily. For MSME players, this is certainly a marketing set-up to achieve targets effectively and efficiently.

\section{DISCUSSION}

Humanistic marketing is one of the marketing movements or programs that began to develop in 2011. As explained in the literature review, in 2011 Porter and Kramer revealed that a developing perspective was "what is good for society is good for business" [5]. From this perspective, the concept of humanistic marketing covers 3 aspects, which are; vision, business goals and processes, and social impact.

Humanistic marketing is not only done by large companies, but small and medium companies are also expected to be able to do humanistic marketing as an effort to attract consumers. One of the Small and Medium Enterprises in Bandar Lampung that has conducted CSI is Diskusi Kopi. Diskusi Kopi has realized the usefulness of a program based on social movements and conservation. As a business, Diskusi Kopi realizes that there are a lot of competitions to face. There are many strategies that are used by the same business actors like Diskusi Kopi in order to attract consumers. One thing why Diskusi Kopi has a different value comparing to competitors, one of these are thoughts that; "sharing, then the business will run well". And this is one aspect of humanistic marketing, called as a "vision" of a sustainable company. From this thought then Diskusi Kopi initiated to do and invite the surrounding small businesses to be able to share with others. This is in line with Kotler and Kramer's statement that what is good for society is good for business [10].

Another aspect of humanistic marketing is business goals, which are gaining for profit. In this study, it can be seen that Diskusi Kopi business actors understand that the Corporate social initiative model can be used as a marketing strategy in increasing market share and sales, in addition to promote their products through social media, Instagram. This is in line with what was said by Kotler and Lee [3] who stated that "at this time companies do something generous are no longer due to obligations, but now what a company gives to the community is a business strategy". Therefore, many business actors apply this business strategy which is doing what is best for the environment and society.

The last aspect that can be achieved in humanistic marketing is social impact. This research shows that there is a positive image which is obtained after the Coffee Discussions and MSME players run the program based on the initiative and the invitation to do mutual cooperation as a symbol of diversity. In the implementation of humanistic marketing, business actors are required to have awareness of the 
importance of social responsibility (CSR) and share with others. With these awareness, a new social responsibility (CSR) model is formed, called as the Corporate Social Initiative (CSI).

One of the CSI programs which Diskusi Kopi runs is TGIF. This program can increase the enthusiasm of visitors to buy the products offered at Diskusi Kopi. In addition, this program can be an effective promotion strategy through social media, because alot of people become followers on Instagram. The findings in this study indicate a conscious change in consumer behavior continuing to represent the positive image of MSMEs in sustainability program. This is in accordance with the results of research by Fraj-Andreas et al. [11] which revealed that small and medium enterprises carry out corporate social responsibility (CSR) based on several things; the values possessed by business actors, market pressures and regulations / law. SMEs have a positive income when carrying out CSR, although only business actors who are proactive and consistent can build a good image and strong position, it is greatly different with business actors who are reactive and opportunistic in gaining profit. The social initiative done by Diskusi Kopi is a marketing strategy to gain a competitive advantage, the results of this study support the research results of Bronn and Cohen's [12] that a company has a motive to be involved in social initiatives.

By the awareness of "working well and doing good", business actors are more focused on selecting several strategic areas which are in line with company values; choosing initiatives that support business goals. In the future the business actors will have new targets and insights that the consumers is not only limited through offline or physical action but also they can emphasize the perspective of consumers in digital platforms, which most of them have limited access and in other hand it can reach wider for the target market from one country to another while maintaining a positive image. It also supports the findings of Abden, et al. [13], which stated that CSR has a relationship with consumer support and consumer purchasing behavior. The results of his research also show that good business ethics has a direct influence on consumer purchasing behavior.

\section{CONCLUSION}

This research focuses on research developing model of CSI in MSME actors on consumer behavior through a social program that has a great relationship between personal and community in representing a brand for the sustainability of a business. Overall, the empirical support from this study is consistent with the results of previous studies that consumers in Indonesia, especially the youths, are able to make a brand as a self-entity in the form of real action through the idea of a responsible social program as part of the existence and connection among consumers. Collaboration is the key and source of consumer interest in seeing the information presented through various network platforms. The development of the CSI model for MSME actors implies that digitalization has an important role for the sustainability of various CSI models.

\section{REFERENCES}

[1] Akumindo, The growth of MSMEs by 10\% in the 2018-2019 period, 2020

[2] D. Jamali, "The CSR of MNC subsidiaries in developing countries: global, local, substantive or diluted?," J. Bus. Ethics, vol. 93, no. 2, pp. $181-200,2010$

[3] P. Kotler and N. Lee, Corporate Social Responsibility; Doing the Most Good you're your Company and Your Cause. NewJersey: JohnWiley\& Sons,Inc., 2005

[4] M.R. Kramer and M. Porter, Creating shared value, vol. 17. FSG, 2011.

[5] L. Hendriani and G. Tjahjono., Indonesia's Best Practice of Corporate Social Initiative. Jakarta: PT Swasembada Media Bisnis, 2018

[6] New Zealand Trade and Enterprise. 2008.

[7] Y.-S. Lii, "The effect of Corporate Social Responsibility (CSR) initiatives on consumers identification with companies," African J. Bus. Manag., vol. 5, no. 5, pp. 1642-1649, 2011.

[8] A. Pomering and S. Dolnicar, "Assessing the prerequisite of successfu CSR implementation: are consumers aware of CSR initiatives?, J. Bus. ethics, vol. 85, no. 2, pp. 285-301, 2009.

[9] L.J. Moleong, "Metodologi Penelitian Kualitatif. Bandung: PT Remaja Rosdakarya.," Metodol. Penelit. kualitatif (edisi revisi), 2004

[10] P. Kotler, "Kellogg on branding: The marketing faculty of The Kellogg School of Management," 2011.

[11] E. Fraj-Andrés, M.E. López-Pérez, I. Melero-Polo, and R Vázquez-Carrasco, "Company image and corporate social responsibility: reflecting with SMEs' managers," Mark. Intell. Plan., 2012.

[12] P.S. Brønn and D. Vidaver-Cohen, "Corporate motives for social initiative: Legitimacy, sustainability, or the bottom line?," J. Bus. Ethics, vol. 87, no. 1, pp. 91-109, 2009.

[13] A. Abdeen, E. Rajah, and S. S. Gaur, "Consumers' beliefs about firm's CSR initiatives and their purchase behaviour,” Mark. Intell. Plan., 2016. 